\title{
Efektywność hamowania odzyskowego w zelektryfikowanym transporcie szynowym
}

\begin{abstract}
Hamowanie odzyskowe jest powszechnie stosowane w nowoczesnych pojazdach trakcyjnych ze względu na szereg zalet. Wprowadzenie pojazdów wyposażonych w uktady hamowania odzyskowego na odcinki funkcjonujacej linii zelektryfikowanego transportu, na których taki tabor wcześniej nie byt w użyciu powoduje konieczność rozpatrzenia szeregu nowych wymagań wobec urzqdzeń infrastruktury zainstalowanej na linii. W artykule przedstawiono stosowane rozwiqzania techniczne, $w$ tym wykorzystanie zasobników energii, które pozwalaja na zwiększenie efektywności hamowania odzyskowego. Omówiono także wyniki prowadzonych przez autora prac $w$ zakresie analiz studialnych dotyczacych modernizacji i rozbudowy układów zasilania trakcji miejskiej przy wprowadzaniu do eksploatacji nowoczesnego taboru.
\end{abstract}

\section{Wprowadzenie}

Wprowadzenie wymogu wzrostu udziału energii 'ekologicznej' (z odnawialnych źródeł) zużywanej przez odbiorców zwiększa zainteresowanie wykorzystaniem energii hamowania, jako tej, która już została dostarczona do pojazdu ze źródła energii pierwotnej i może być ponownie wykorzystana (odzyskana) albo wytracona w postaci ciepła.

Rozwój układów napędowych $\mathrm{z}$ przekształtnikami takimi jak czopery $\mathrm{z}$ silnikami prądu stałego, a w szczególności falowniki z silnikami prądu przemiennego umożliwił zwiększenie odzysku energii hamowania, która może zostać:

a.)zużyta przez inne pojazdy znajdujące się na tej samej sekcji zasilania,

b.) przesłana do podstacji trakcyjnej, w której znajduje się zasobnik gromadzący energię lub przetworzona przez falowniki na energię prądu przemiennego przesłaną do sieci,

c.)zgromadzona w zasobniku energii na pojeździe.

Do zalet stosowania systemów hamowania odzyskowego należą:

$>$ ograniczenie wydzielania ciepła w hamulcach mechanicznych lub rezystorach hamowania elektrycznego,

$>$ zmniejszenie zużycia hamulców ciernych i kół,

$>$ ograniczenie zanieczyszczeń (od hamul-ców ciernych),

$>$ zmniejszenie zużycia energii i mocy szczytowej, obniżenie kosztów.

\section{Efektywność hamowania odzyskowego}

Proces odzyskiwania energii hamujących pojazdów należy rozpatrywać globalnie dla całego systemu zelektryfikowanego transportu, począwszy od taboru, a kończąc na układzie zasilania i sterowania.

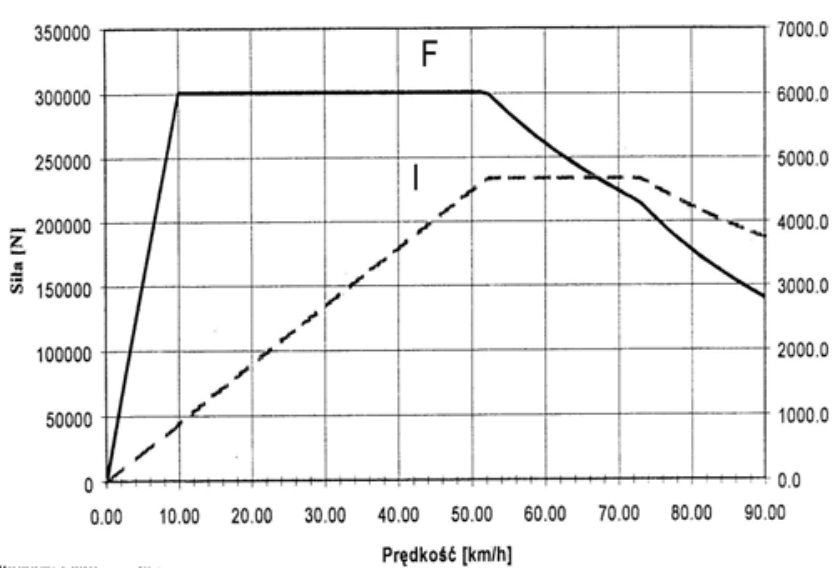

Rys. 1 Przykładowa charakterystyka hamowania pojazdu trakcyjnego

Konkretny tabor ma zwykle zdefiniowane warunki i wymagania co do poprawnej pracy, w tym hamowania odzyskowego. Zdolność pojazdu do oddania energii, określona poprzez jego charakterystyki (przykładowa przedstawiona jest na rys. 1) nie jest warunkiem wystarczającym do jej odzysku, niezbędny jest odbiornik tej energii o wymaganej pojemności energetycznej jak i układ zasilania zdolny do przesłania energii od pojazdu hamującego odzyskowo do pojazdu pobierającego prąd. Aby energia została przesłana muszą zostać spełnione warunki transferu, tzn. napięcie w punkcie rekuperacji musi być odpowiednio wyższe od napięcia $\mathrm{w}$ punkcie odbioru (na pojeździe lub w podstacji),

Istotna jest także wartość rezystancji na drodze przepływu prądu rekuperacji, która zależy od:

- schematu sekcjonowania,

- odległości między podstacjami,

- rezystancji jednostkowej sieci trakcyjnej i szyn jezdnych,

- charakterystyki (pochylenia) podstacji trakcyjnej. 
Efektywność rekuperacji energii do innych pojazdów zależeć będzie także od liczby pojazdów, które znajdować się będą w strefie (obszarze zasilania), do której rekuperujący pojazd może dostarczyć energię i relacji czasu hamowania do czasu poboru energii oraz prawdopodobieństwa nałożenia się cykli hamowanie/pobór energii.

Wykorzystanie hamowania odzyskowego można zwiększyć poprzez:

$>$ wydłużenie sekcjonowanych obszarów zasilania (zasilanie dwu lub wielostronne z kilku zasilaczy-podstacji), co zwiększy liczbę pojazdów w strefie przekazywania energii,

$>$ zwiększenie różnicy napięcia pomiędzy napięciem na pantografie hamującego pojazdu i w najbliższej podstacji (zwykle napięcie rekuperacji ustalane jest na najwyższym możliwym poziomie, dlatego zwiększenie tej różnicy zasadniczo jest możliwe poprzez zmniejszenie napięcia podstacji czyli stosowanie prostowników sterowanych), W normie PNEN 50163 dla sieci trakcyjnych deklarowane są wartości napięć, które nie mogą być przekraczane. Jeśli jest to niezbędne (tzn. występuje przekroczenie dopuszczalnych wartości napięć), należy zmniejszyć napięcie rekuperacji lub zastosować wytracanie energii na rezystorze w pojeździe lub w podstacji trakcyjnej albo wyposażyć podstacje trakcyjne $\mathrm{w}$ falowniki, co umożliwi zwrot energii do sieci zasilającej w przypadku, gdy nie ma na odcinku pojazdów pobierających energię,

$>$ zmniejszenie rezystancji na drodze przepływu energii rekuperacji (zmniejszenie strat i spadków napięć), co wymaga znacznych inwestycji w układzie zasilania,

$>$ zastosowanie odbiorników energii (zasobników w podstacjach lub pojazdach albo falowników w podstacjach do przesyłu energii do sieci zasilającej).

Wybór działań, które należy wprowadzić wymaga przeprowadzenia szczegółowych analiz dotyczących wpływu tego typu rozwiązań na system zelektryfikowanego transportu, a w szczególności oceny:

$>$ warunków napięciowych i zwarciowych w nowej konfiguracji układu zasilania (minimalne prądy zwarcia przy dłuższych sekcjach i obniżonym napięciu podstacji, zdolność wyłączania zwarć dosilanych z sąsiednich podstacji, stosowania wyłączników szybkich niespolaryzowanych o większej zdolności łączeniowej),

$>$ konieczności instalowania inteligentnych systemów w taborze i układach zasilania,

$>$ oddziaływania systemu zelektryfikowanego transportu na infrastrukturę techniczna (harmoniczne, moc bierna, prądy błądzące) i bezpieczeństwo eksploatacji.

\section{Zasobniki energii}

W ostatnim okresie ponownie wzrosło zainteresowanie zasobnikami energii. Związane jest to $\mathrm{m}$. in. $\mathrm{z}$ rozwojem nowych technologii w zakresie możliwości magazynowania energii. Zasobniki energii, które można stosować w trakcji elektrycznej zaliczamy do jednej z grup:

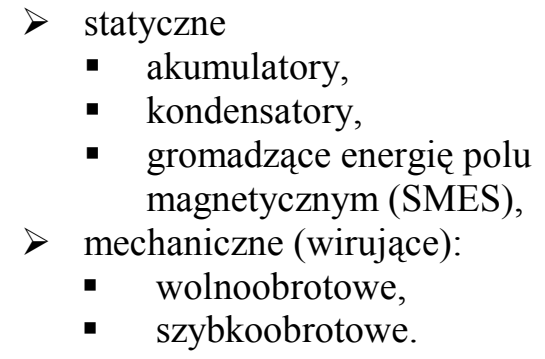

Przykładowe zakresy gęstości energetycznej (mocy i energia na jednostkę masy) zasobników przedstawione są na rysunku 2:

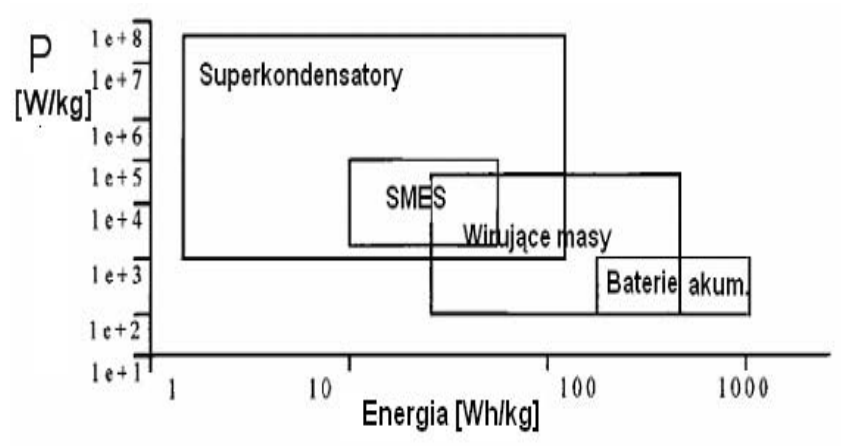

Rys. 2 Gęstość energetyczna zasobników wg. [9]

Zasobniki wirujące zasadniczo stosowane są, ze względu na gabaryty, jedynie w podstacjach. Nowe typy superkondensatorów przy tych samych wymiarach mają wielokrotnie większą pojemność niż kondensatory klasyczne. Z kolei ich moc ciagła i cykl użytkowania (powyżej 500000 ładowań) są też większe niż akumulatorów. Ze względu na niskie napięcie pojedynczego kondensatora do łączenia kondensatorów w grupy wymagane są odpowiednio sterowane układy elektroniczne.

Wykorzystanie zasobników energii i falowników w podstacjach trakcyjnych lub w pojeździe oraz ich efektywność powinna być rozpatrywana, ze względu na różnorodne warunki pracy systemów transportu indywidualnie dla każdego $\mathrm{z}$ nich

z uwzględnieniem uwarunkowań technicznych oraz finansowych i ekonomicznych efektów w odniesieniu do danego rozwiązania. Zanim podejmie się decyzje o zastosowaniu tego typu rozwiązania niezbędne jest określenie technicznych i finansowych celów, jakie chce się przez nie osiągnąć. 
Efekty jakie może dać zastosowanie zasobników energii to:

$>$ zmniejszenie szczytów i wyrównywanie obciążeń dzięki zmniejszeniu zapotrzebowania na moc szczytową i zmniejszenie kosztów zamawianej mocy,

$>$ wzmocnienie układu zasilania i poprawa warunków napięciowych,

$>$ zmniejszeniu obciążenia systemu i wyrównywanie obciążeń w okresach zwiększonego zapotrzebowania na energię $\mathrm{z}$ systemu (gromadzenie energii z zasobniku, gdy zapotrzebowanie na energię jest niewielkie i oddawanie w godzinach szczytu poboru z systemu elektroenergetycznego),

$>$ zwiększenie sprawności i dynamiki jazdy pociagów (charakterystyka trakcyjna zależy od napięcia),

$>$ wydłużenie odległości pomiędzy podstacjami,

$>$ poprawa warunków zasilania w przypadku awarii; energia zgromadzona w zasobniku pozwala na dojechanie pociagów do stacji w przypadku zaniku napięcia zasilającego,

$>\quad$ stosowanie zasobnika (dzięki małym wymiarom i braku przyłącza do sieci energetycznej) jako przewoźnej podstacji,

Zasobniki moga pracować, w zależności od wyboru algorytmu pracy, w różnych trybach:

$>$ gromadzenie-oddawanie energii:

○ wstępne podładowanie,

○ przy wzroście napięcia w sieci (gdy na odcinku znajduje się pojazd hamujący odzyskowo) - energia wpływa do zasobnika przy napięciu nieco wyższym niż napięcie podstacji (brak dosilania z podstacji),

- gdy napięcie sieci spadnie do poziomu w zakresie nastawy napięcia zasobnika ładowanie ustaje,

- rozładowanie zasobnika następuje gdy pojawi się odbiór energii (pojazd).

wyrównywanie obciążeń:

○ wstępne naładowanie,

- gdy napięcie spada przy poborze energii zasobnik zasila sieć, napięcie podnosi się tylko do wartości poniżej minimalnego napięcia zasilania sąsiedniej podstacji,

- gdy napięcie w sieci wzrośnie, zasobnik przestaje oddawać energię do sieci,

- ładowanie zasobnika energią $\mathrm{z}$ sąsiedniej podstacji.

\section{Analiza efektywności wprowadzanie pojazdów $z$ hamowaniem odzyskowym}

W ostatnich latach znacząco zwiększyła się w Polsce liczba nowoczesnego taboru wyposażonego w możliwość hamowania odzyskowego, przede wszystkim w trakcji miejskiej. Przy wprowadzeniu do ruchu pojazdów trakcyjnych wyposażonych w układy hamowania rekuperacyjnego zwykle mamy do czynienia $\mathrm{z}$ istniejąca infrastrukturą techniczną linii, która nie była przewidziana do zasilania taboru $\mathrm{z}$ odzyskiem energii, a po której poruszać się będą pojazdy o różnorodnym wyposażeniu. Powoduje to konieczność szczegółowego przeanalizowania warunków pracy systemu elektroenergetyki trakcyjnej ze względu na specyficzne wymagania tych pojazdów.

Należy zatem postawić pytanie: jak wprowadzenie do eksploatacji nowego taboru $\mathrm{z}$ napędem przekształtnikowym, zwykle o większej mocy z możliwością odzysku energii wpłynie na pracę układu zasilania projektowanego dla innych założeń dotyczących podstawowych parametrów i wielkości charakterystycznych tego układu.

Przy podejmowaniu decyzji o zastosowaniu rozwiązań poprawiających efektywność hamowania odzyskowego należy uwzględnić:

a.) częstość ruchu taboru i jego prędkości oraz moce i charakterystyki,

b.) profil trasy i położenie przystanków,

c.) układy sekcjonowania i zasilania linii po stronie $\mathrm{DC}$,

d.) rezystancje w obwodach $\mathrm{DC}$,

e.) dopuszczalny poziom napięć w sieci trakcyjnej,

f.) bilans energii w systemie transportowym,

g.) dodatkowe koszty wyposażenia taboru/podstacji lub jakie oszczędności można uzyskać wprowadzając te rozwiązania (analiza efektywności finansowej i ekonomicznej).

Przy niewielkich nadwyżkach możliwej do oddania energii nad energią, którą są zdolne pobrać inne pojazdy nie jest zwykle opłacalne stosowanie dodatkowych urządzeń do przejmowania energii w taborze czy podstacjach, choć jest to najbardziej korzystne $z$ punktu widzenia sprawności energetycznej układu. Bowiem zainstalowanie urządzeń umożli-wiających zwrot energii do sieci energetycznej (lub jej gromadzenie w zasobnikach) pozwala zagospodarować praktycznie całą energię odzyskiwaną $\mathrm{z}$ pojazdu (z uwzględnieniem strat przesyłowych).

\section{Przykładowe wyniki analiz}

W Zakładzie Trakcji Elektrycznej Politechniki Warszawskiej opracowano metodykę modelowania systemów zelektryfikowanego transportu $\mathrm{z}$ uwzględnieniem taboru hamującego odzyskowo oraz możliwością zastosowania zasobników energii. Metodyka ta 
została zaimplementowana $\mathrm{w}$ postaci programów symulacyjnych do analiz efektywności hamowania odzyskowego i zastosowane w analizach dotyczących koncepcji zasilania trakcji miejskiej $[3,14,15,16,17]$. Przykłady wyników analiz i symulacji zestawiono poniżej.

\subsection{Wpływ ruchu pojazdów metra na efektywność odzysku energii}

W systemie metra ruch odbywa się co prawda bezkolizyjnie, ale istotny jest sposób prowadzenia jazdy i wzajemne korelacje strumieni ruchu w obu kierunkach, prędkości maksymalne oraz odległości międzyprzystankowe.

Przyjmijmy następujące założenia dla linii metra: podstacje rozmieszczone na co drugiej stacji, odstęp czasowy pomiędzy pociągami jadącymi w tym samym kierunku 210 sekund, sprawność przekazywania energii oddawanej przez pociąg przy hamowaniu:90 \%, masa pociagu 300 ton, prędkość maksymalna 65 $\mathrm{km} / \mathrm{h}$, profil płaski [10].

Na rys. 3 przedstawiono wpływ czasowego przesunięcia strumieni regularnego ruchu jednego kierunku względem drugiego (przesunięcie oznacza opóźnienie startu strumienia jednego kierunku względem drugiego) oraz odległości międzystacyjnej na jednostkowe zużycie energii jze. Na rys. 4 pokazano przebieg wpływu przesunięć strumieni ruchu i odległości międzystacyjnej na stopień wykorzystania potencjalnej

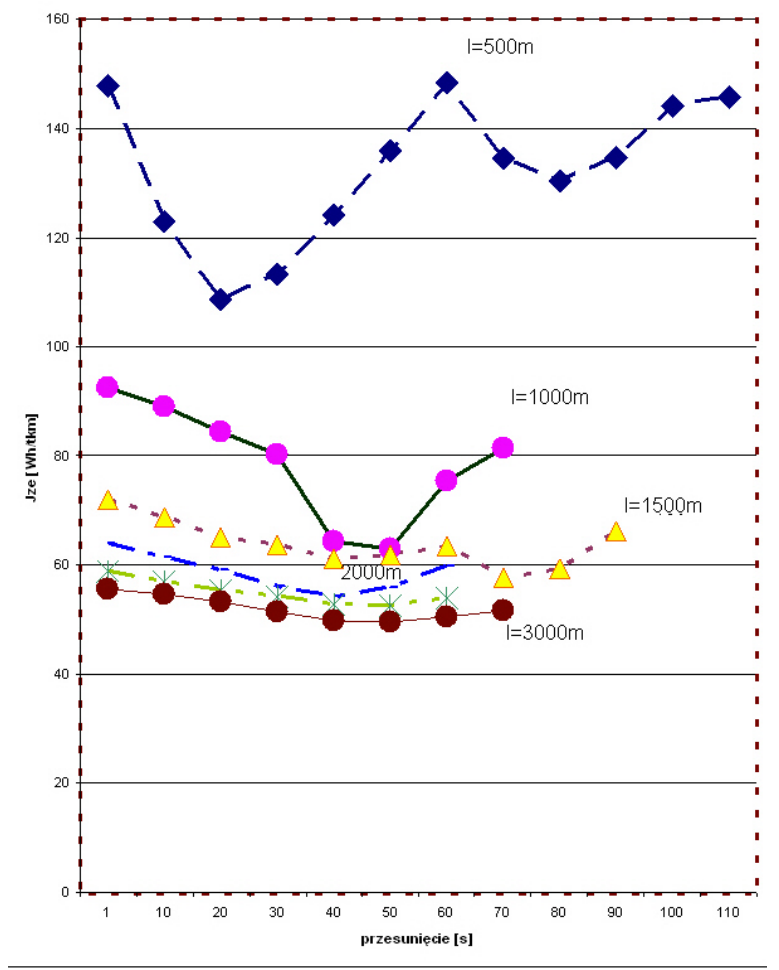

Rys.3 Wpływ przesunięcia strumieni ruchu na kierunkach ruchu oraz odległości międzyprzystankowej na jze. możliwości rekuperacji pojazdu zdefiniowanej stosunkiem wartości energii oddanej do sieci przez pojazdy $E_{\text {ro }}$ (tzn. przesłanej do innych pojazdów) do energii teoretycznie możliwej do oddania $\mathrm{E}_{\mathrm{rp}}$, gdyby układ zasilania był w pełni receptywny (zdolny do przejęcia energii). $Z$ kolei na rys. 5 przedstawiony jest przebieg stosunku energii $E_{\mathrm{rp}}$ do energii pobranej $\mathrm{z}$ podstacji trakcyjnych $\mathrm{E}_{\mathrm{pt}}$, , co oznacza teoretyczną maksymalną możliwość odzysku energii dla danych warunków. Jak można zaobserwować, choć stosunek $\mathrm{E}_{\mathrm{ro}} / \mathrm{Er}_{\mathrm{p}}$, osiagga maksymalną wartość 0,65 , ale w większości przypadków nie przekracza 0,5 . Oznacza to, że w praktyce mniej niż połowa możliwej do odzysku energii $E_{\text {rp }}$ jest wykorzystana, a która mogłaby być, przy zainstalowaniu zasobników, odzyskana. Z kolei na rys. 6 przestawiono wpływ przesunięć i profilu na jze.

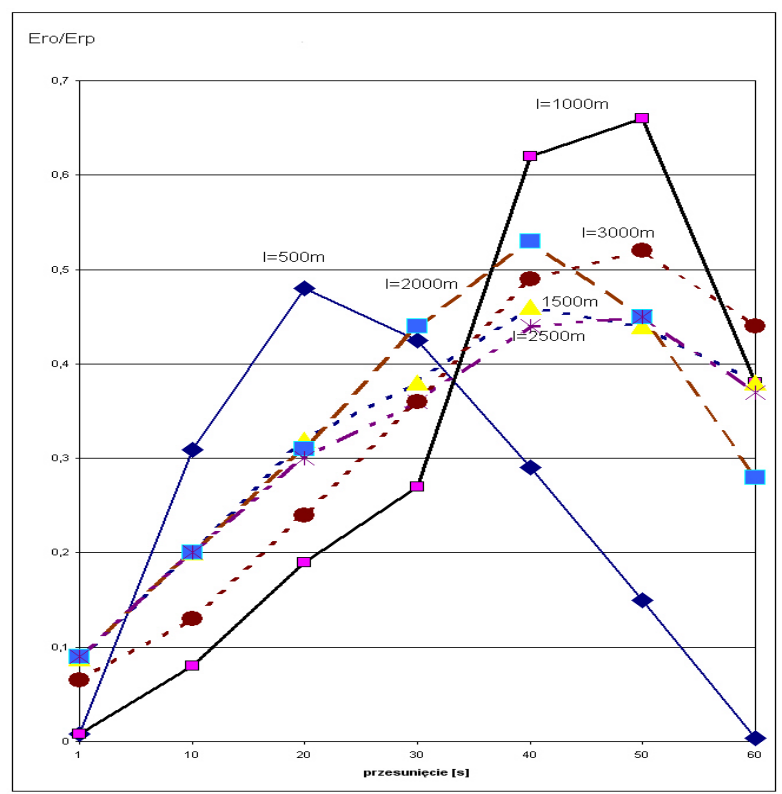

Rys.4 Relacja $\mathrm{E}_{\mathrm{ro}} / \mathrm{E}_{\mathrm{rp}} \mathrm{W}$ zależności od przesunięć strumieni ruchu i odległości międzyprzystankowej.

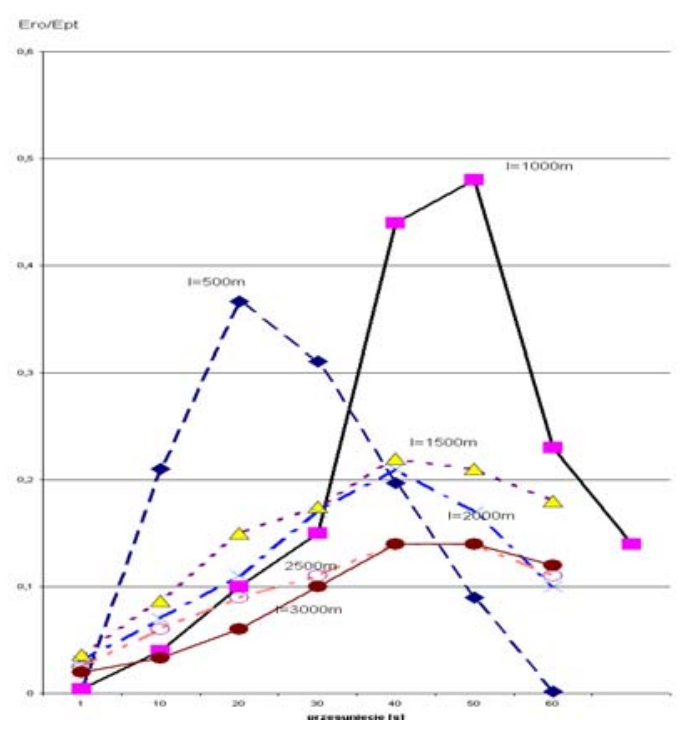

Rys. 5 Relacja $\mathrm{E}_{\mathrm{ro}} / \mathrm{E}_{\mathrm{pt}} \mathrm{W}$ zależności od przesunięć strumieni ruchu i odległości międzyprzystankowej 


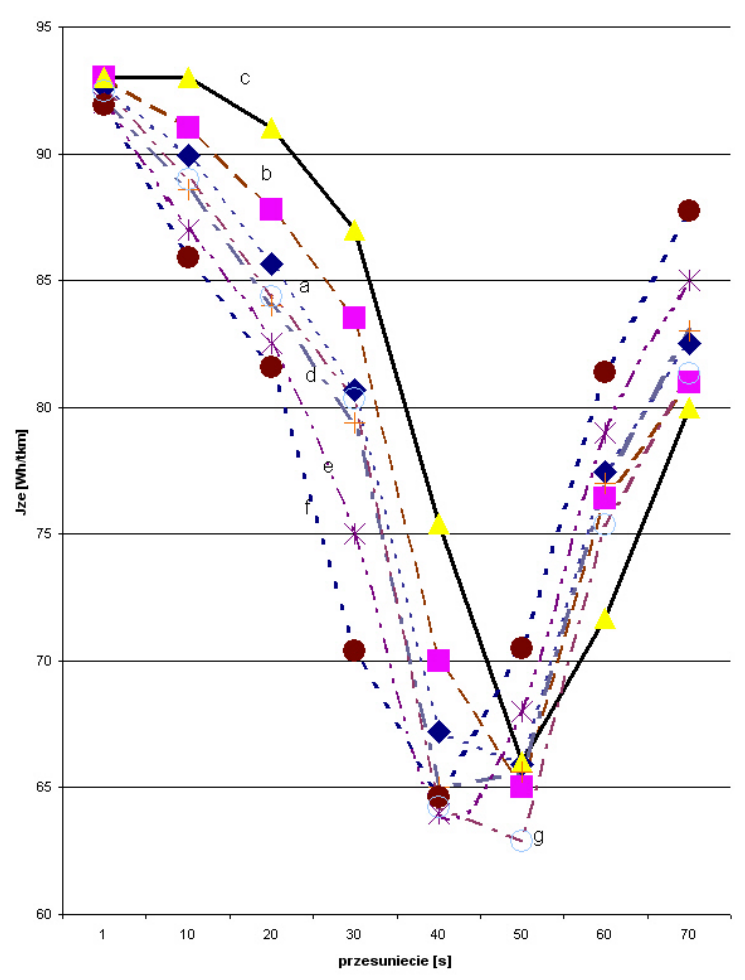

Rys.6 Wpływ przesunięcia strumieni ruchu na kierunkach ruchu oraz profilu na jze, a) +2 promille,b) $+6, \mathrm{c})+10$, d) -2, e) -6, f) -10 g) 0

\subsection{Zastosowanie zasobnika energii $w$ podstacji metra}

W pracy dotyczacej koncepcji zasilania II linii Metra Warszawskiego zaproponowano zainstalowanie zasobnika energii. Celem budowy takiej podstacji zasobnikowej, oprócz możliwości zwiększenia efektywności odzysku energii hamujących pojazdów metra, szczególnie na odcinku o dużym pochyleniu (rys. 7,8symulacja przejazdów taboru metra na linii) było zmniejszenie obciążeń podstacji $\mathrm{w}$ warunkach normalnych (rys.9, moc średnia zmniejszyła się o $20 \%$ ) i awaryjnych, ale także zgromadzenie energii umożliwiającej wyjazd pociagu metra $\mathrm{z}$ tunelu pod Wisłą w przypadku awarii zasilania.

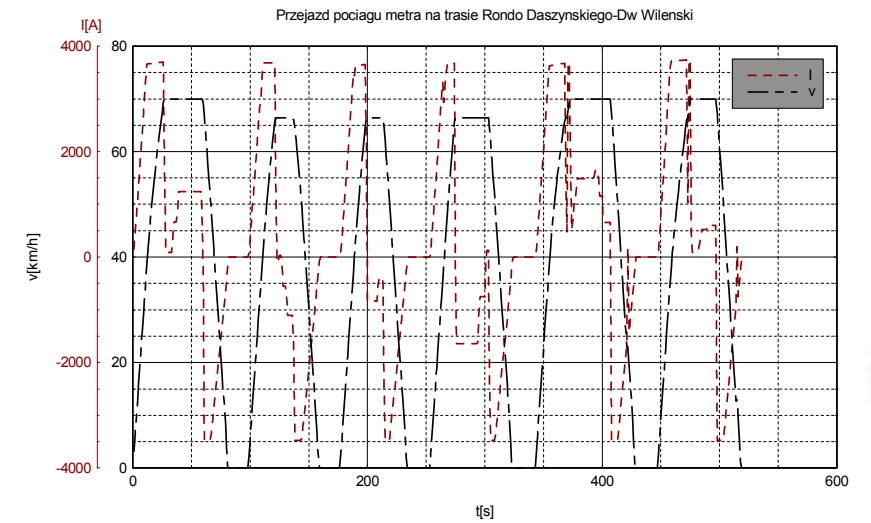

Rys. 7 Symulacja przejazdu (prędkość, prąd) pociagu metra na centralnym odcinku II linii kierunek 'tam'(pociag 6-wag., 4 wagony napędne)

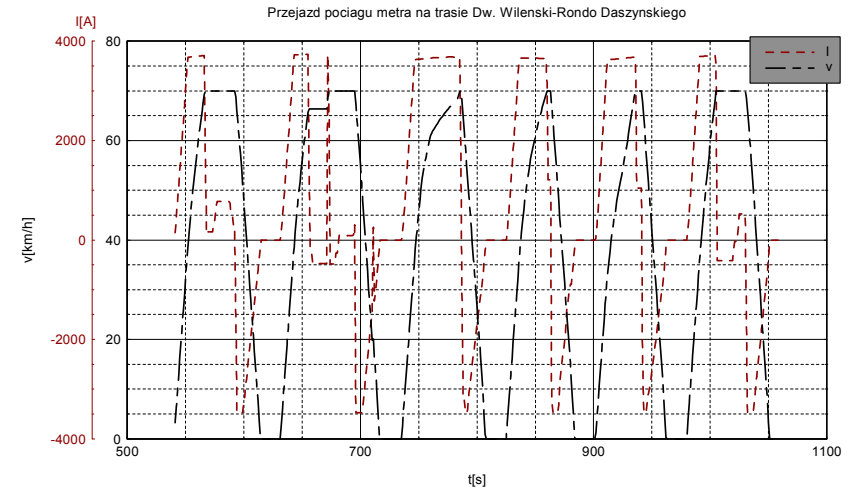

Rys.8 Symulacja przejazdu (prędkość, prąd) pociagu metra na centralnym odcinku II linii kierunek 'powrót'(pociąg 6-wag. , 4 wagony napędne)

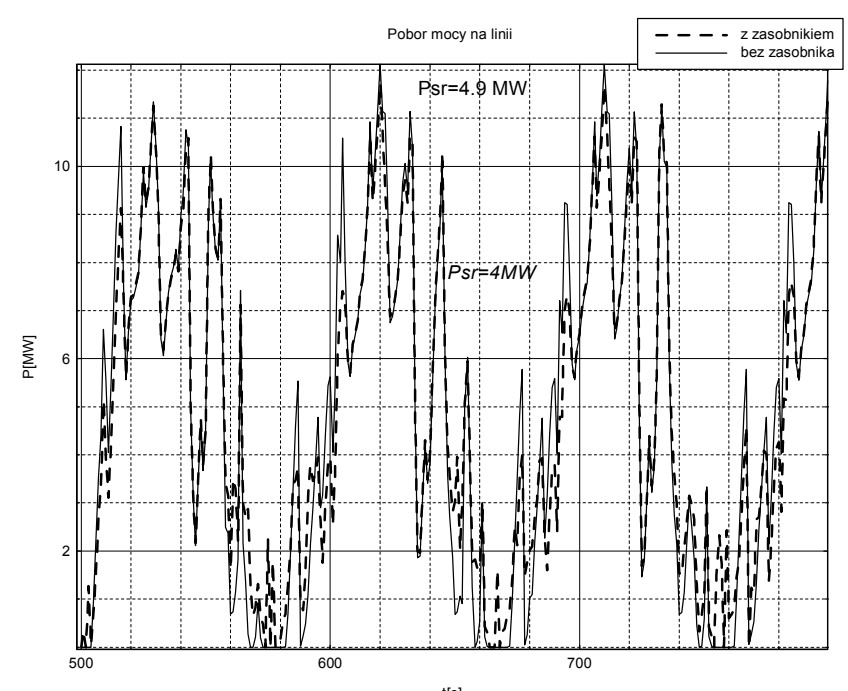

Rys.9 Przebieg obciążenia jednej z prostownikowych podstacji trakcyjnych dla wariantu $\mathrm{z}$ zasobnikiem w warunkach normalnej pracy (przebieg przerywany) i bez zasobnika (przebieg ciagły).

\subsection{Hamowanie odzyskowe w trakcji tramwajowej}

Przy opracowywaniu jednej z koncepcji systemu zasilania trakcji tramwajowej [16] rozważono wariant $\mathrm{z}$ zastosowaniem zasilania dwustronnego, co pozwoliło na zwiększenie długości zasilanych sekcji, zapewnienie rezerwowania $\mathrm{w}$ warunkach awaryjnych oraz poprawę wykorzystania energii hamowania odzyskowego. Wyniki uzyskane z analiz przedstawiono poniżej z porównaniem ruchu nowoczesnym taborem z możliwością hamowania odzyskowego (rys. 10,12,14) jak i bez (rys.11,13,15).

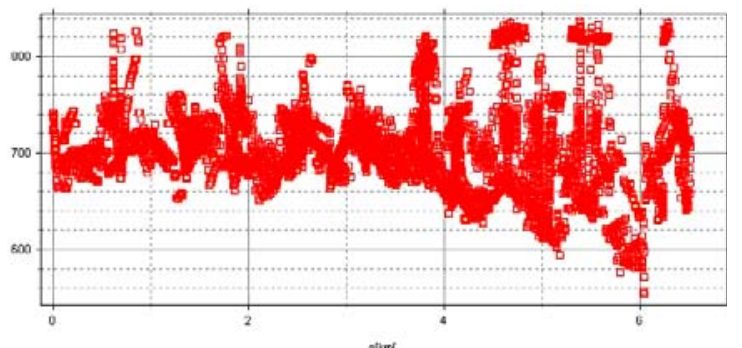

Rys. 10 Zestawienie wartości napięć na odbierakach tramwajów $\mathrm{w}$ funkcji położenia (wariant $\mathrm{z}$ hamowaniem odzyskowym - ho) 


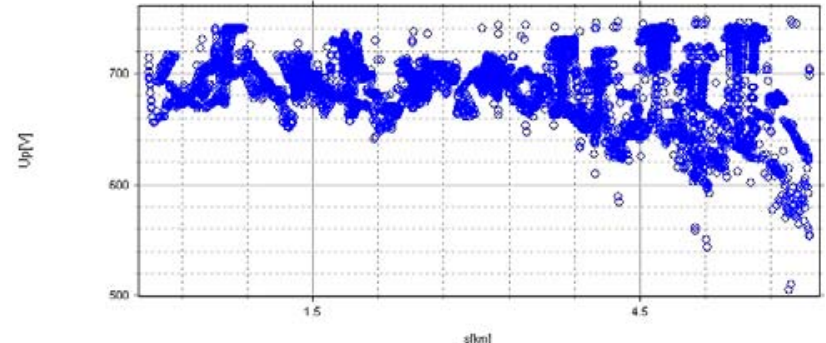

Rys. 11 Zestawienie wartości napięć na odbierakach tramwajów w funkcji położenia (wariant bez hamowania odzyskowego - bho)

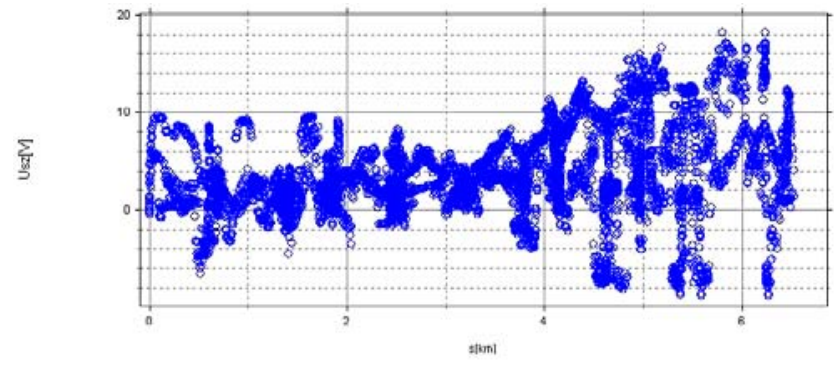

Rys. 12 Zestawienie wartości napięć w szynach w funkcji położenia tramwaju(wariant $\mathrm{z}$ ho)

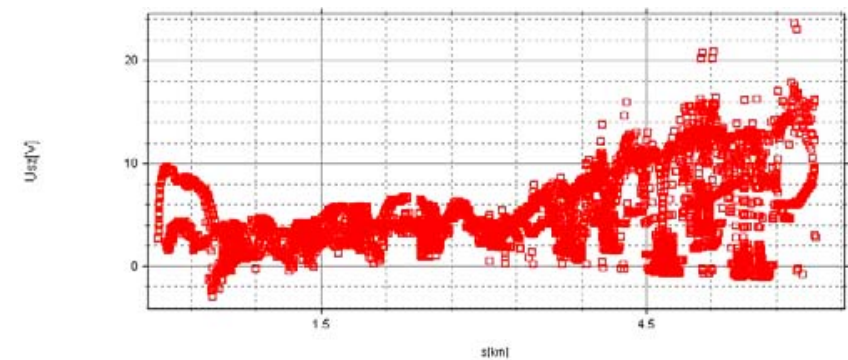

Rys. 13 Zestawienie wartości napięć w szynach w funkcji położenia tramwaju (wariant bho)

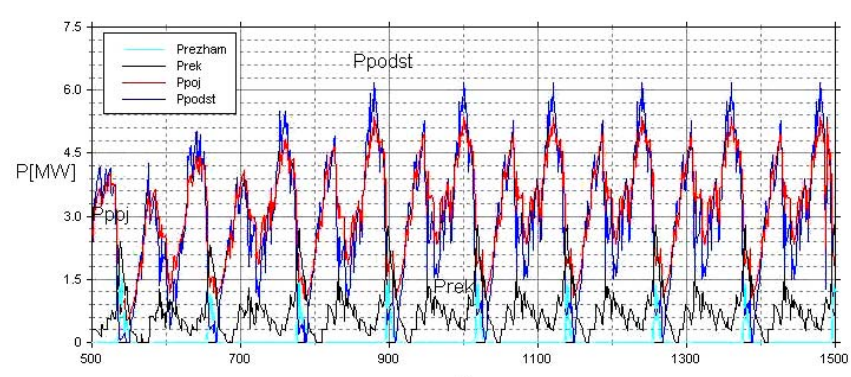

Rys. 14 Zestawienie przebiegu mocy chwilowej obciążenia

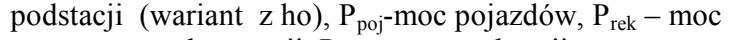
rekuperacji, $\mathrm{P}_{\text {podst }}-$ moc podstacji

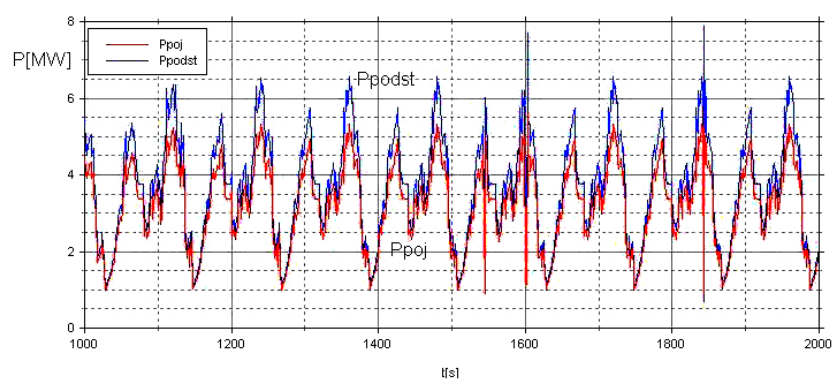

Rys. 15 Zestawienie przebiegu mocy chwilowej obciążenia podstacji (wariant bho), $\mathrm{P}_{\text {poj }}$-moc pojazdów, $\mathrm{P}_{\text {podst }}$-moc podstacji.

\subsection{Układ zasilania linii WKD}

W pracy dotyczącej modernizacji układu zasilania linii WKD [19] ze względu na prognozowane znaczne zwiększenie ruchu i wprowadzenie nowego taboru o większej mocy z możliwością hamowania odzyskowego, rozpatrzono opcję zasilania napięciem $750 \mathrm{~V}$ DC z zastosowaniem zamiast dodatkowych podstacji trakcyjnych podstacji zasobnikowych. Przykładowe wyniki symulacji zestawiono na rys. 16-21. Na rysunkach pokazane jest położenie trasy (kilometraż $0 \div 32$ ) oraz odcinek boczny $\mathrm{z}$ kilometrażem powyżej 50 .

Na rys. 16 pokazano napięcia na odbierakach pociągów w funkcji położenia dla wariantu bez stosowania zasobników energii, zaś na rys.17 z zastosowaniem zasobników. Można zauważyć wpływ zastosowania zasobnika na poziom napięcia $\mathrm{W}$ sieci trakcyjnej (przebieg napięcia zasobnika w funkcji czasu przedstawiono rys. 18) i szynach (rys. 19,20).

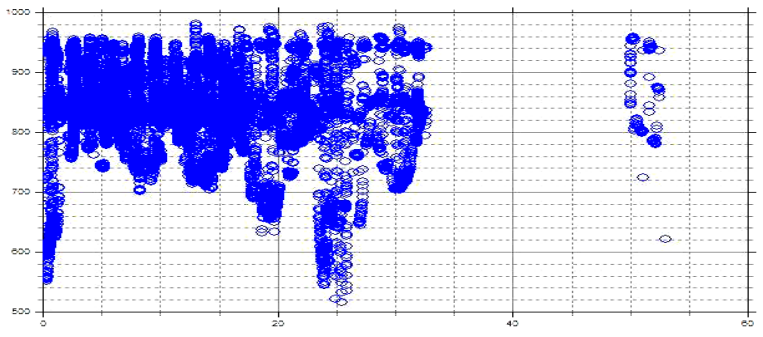

Rys.16 Napięcia na odbierakach pociagów w funkcji ich położenia, wariant bez zasobników

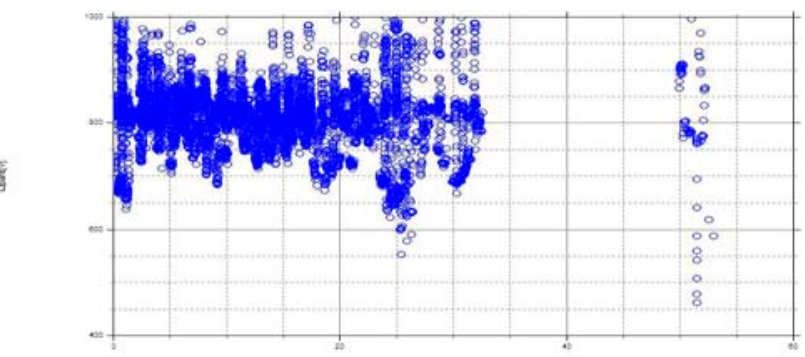

Rys.17 Napięcia na odbierakach pociągów w funkcji ich położenia, wariant $\mathrm{z}$ zastosowaniem zasobników

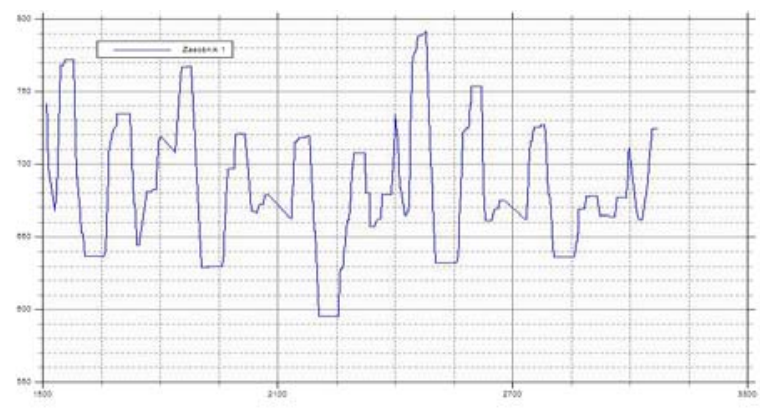

Rys.18 Przebieg napięcia jednego z zasobników 


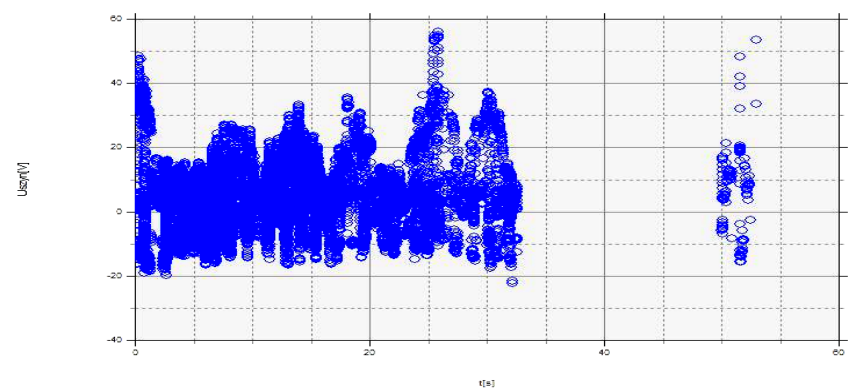

Rys.19 Potencjały szyn jezdnych, wariant bez zasobników.

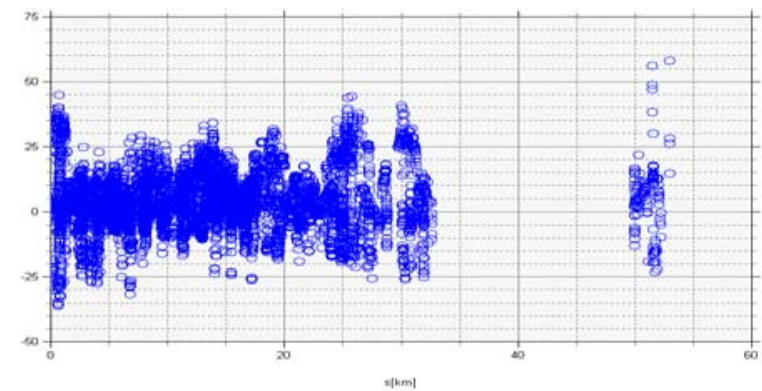

Rys.20 Potencjały szyn jezdnych, wariant z zasobnikami

Dla wariantu z zastosowaniem zasobników (przy założonym ruchu) obliczono, że roczne oszczędności sięgać mogą $856 \mathrm{MWh}$, co zmniejszyłoby emisję $\mathrm{CO}_{2}$ w elektrowniach węglowych o ok. 440 t. Przyjmując koszt $1 \mathrm{MWh}$ na poziomie 200PLN oszczędności te wyniosą ok. 171200 PLN, nie licząc kosztów oszczędności w opłatach za moc szczytową, które powinny być mniejsze o ok. $20 \% \mathrm{w}$ stosunku do wariantu bez zasobników. Oddzielnym zagadnieniem jest kwestia nakładów inwestycyjnych, budowa podstacji zasobnikowej jest znacznie tańsza niż budowa podstacji prostownikowej ze względu na brak zasilania SN. Mimo to wariant niskonapięciowy zasilania WKD (750V DC) był droższy niż wariant zasilania napięciem $3 \mathrm{kV}$ DC.

\section{Podsumowanie}

Zagadnienie oszczędności energii w systemach zelektryfikowanego transportu z pojazdami wyposażonymi w układy hamowania rekuperacyjnego należy rozpatrywać globalnie począwszy od taboru, a kończąc na układzie zasilania i urządzeniach infrastruktury technicznej (systemy sterowania i sygnalizacji). Wykorzystanie różnych rozwiązań technicznych w odniesieniu do systemu zelektryfikowanego transportu w celu zwiększenia odzysku energii oraz ich efektywność powinny być rozpatrywane, ze względu na różnorodne warunki pracy systemu zelektryfikowanego transportu z uwzględnieniem celów jakie chce osiagnąć, możliwych do uzyskania korzyści oraz uwarunkowań technicznych taboru (np. prędkość i jednostkowe zużycie energii na przewidzianej do ruchu trasie) $i$ infrastruktury linii. Należy przy tym stosować specjalizowane narzędzia symulacyjne pozwalające na analizę ruchu pojazdów, rozpływu prądów, spadku napięć oraz bilansu energetycznego w złożonym nieliniowym systemie, jaki stanowi system zelektryfikowanego transportu szynowego. Prace takie powinny poprzedzać etap podejmowania decyzji inwestycyjnych, gdyż konkretny tabor ma zwykle zdefiniowane warunki i wymagania co do poprawnej pracy, w tym hamowania odzyskowego. Zdolność pojazdu do oddania energii, określona poprzez jego charakterystyki hamowania, aczkolwiek istotna, nie jest warunkiem wystarczającym do jej wykorzystania, niezbędny jest odbiornik tej energii o wymaganej zdolności przejęcia energii jak i układ zasilania umożliwiający jej przesłanie od pojazdu hamującego odzyskowo do odbiornika.

\section{Bibliografia}

[1.] Abe S., Fuimori H., Ito T - DC feeding system suitable for rolling stocks with regenerative braking system utilizing thyristor rectifier. EPE'93 Conference,Brighton, UK, 1993

[2.] Fletcher R.G. - Regenerative equipment for railway rolling stock. Power Engineering Journal, May 199

[3.] Kacprzak J., Mierzejewski L., Szelag A., Urbanek R., Sielski R. - Analiza efektywności technicznej hamowania rekuperacyjnego wa-gonów METROPOLIS seria TC/M. produkcji ALSTOM w aspekcie możliwości obecnego zasilania w Metrze Warszawskim. Praca Zaktadu Trakcji Elektrycznej IME PW na zlecenie Metra Warszawskiego (nie publikowane), 1999-2000

[4.] Kemp R.J. - Introduction of chopper controlled trains on established DC railways. IEE Proc., Vol. 134, PtB., No3, May, 1987

[5.] Makoto Kuwabara, Akira Ito, Yasuo Suzuki - Traction Substation for Suburban Train Service. Hitachi Review, Vol. 40 (1991), No 4

[6.] Mellitt B., Mouneimne Z.S., Goodman C.J. - Simulation study of DC transit systems with inverting substations. IEE Proc. Vol. 131, Pt. B, No 2, March, 1984

[7.] Mierzejewski L., Szelag A.: Ground transportation systems. (w: The Encyclopedia of Electrical and Electronic Engineering, Supplement 1:, John Wiley \& Sons, NY, USA, 2000, str. 169-194)

[8.] Nene V.D.- Advanced propulsion systems for urban rail vehicles. 1980

[9.]Ribeiro P. F. Brian K. Johnson, Mariesa L. Crow, Aysen Arson, Yilu Liu - Energy Storage Systems for Advanced Power Applications

[10.] Słodkowski M.- Optymalizacja ruchu pociagów metra ze względu na efektywność hamowania odzyskowego, praca dyplomowa, Zakład Trakcji Elektrycznej PW, 2008

[11.] Sone S., S. Ishizu - Reassessment of Power Feeding Systems at Introducing Regenerative Trains. IEE Int. Conference on Electric Railway Systems for a New Century. Sept.1987

[12.] Sugimoto T. - Coefficient of regenerative energy for commuter and light-traffic railways. COMPRAIL 2000 Conference, IX, Bologna

[13.] Suzuki T. - DC power supply system with inverting substations for traction systems using regenerative brakes. IEE Proc. Vol. 129, Pt 8, No 1, January 1982 
[14.] Szelag A.(kier.)- Modele elementów zasilania trakcji elektrycznej $w$ symulacyjnej analizie wspótpracy uktadu system elektroenergetyczny-prostownikowa podstacja trakcyjna - sieć trakcyjna i szynowa-pojazd $z$ energoelektrycznymi układami przetwarzania energii. Projekt badawczy KBN 8 T10A 031 18, 2000

[15.] Szelag A. - Kryteria, standardy techniczne oraz zagadnienia jakości energii elektrycznej w projektowaniu układów zasilania elektroener-getyki kolejowej systemu $3 k V$. Technika Transportu Szynowego $12 / 2008$

[16.] Szelag A. i zespót- Projekt budowy Trasy Mostu Pótnocnego - Studium zasilania trakcji tramwajowej. Praca na zlecenie SchuesslerPlan, 2008

[17.] Szelag A. i zespót - Projekt koncepcyjny układu zasilania odcinka centralnego II linii metra $w$ Warszawie, od Ronda Daszyńskiego do Dworca Wileńskiego. Praca na zlecenie Metroprojektu, Warszawa, 2008
[18.]Szelag A. - Zwiększanie efektywności energetycznej transportu szynowego. Technika Transportu Szynowego 12/2008, s.12-18

[19.] Szelag A. i zespół Zakładu Trakcji Elektrycznej - Analiza możliwości wykorzystania pradu stałego o napięciu $750 \mathrm{~V}$ do zasilania trakcji elektrycznej linii WKD, Praca na zlecenie WKD sp. z o.o., Warszawa, 2009

[20] Szelag A. - Energetyczne aspekty modernizacji taboru $i$ zwiększania prędkości ruchu pociagów elektrycznych, MET2009, 24-26 IX 2009 Gdańsk

[21.] Żukowski R. - Analiza efektywności zastosowania zasobników energii w uktadzie zasilania trakcji miejskiej na przykładzie Metra Warszawskiego, praca dyplomowa, Zakład Trakcji Elektrycznej PW, 2008 